\title{
Ecological predictors and consequences of non-native earthworms in Kennebec County, Maine
}

Julia Rogers

Colby College

Follow this and additional works at: https://digitalcommons.colby.edu/honorstheses

Part of the Forest Biology Commons

Colby College theses are protected by copyright. They may be viewed or downloaded from this site for the purposes of research and scholarship. Reproduction or distribution for commercial purposes is prohibited without written permission of the author.

\section{Recommended Citation}

Rogers, Julia, "Ecological predictors and consequences of non-native earthworms in Kennebec County, Maine" (2016). Honors Theses. Paper 825.

https://digitalcommons.colby.edu/honorstheses/825

This Honors Thesis (Open Access) is brought to you for free and open access by the Student Research at Digital Commons @ Colby. It has been accepted for inclusion in Honors Theses by an authorized administrator of Digital Commons@ Colby. 
Ecological predictors and consequences of non-native earthworms in Kennebec County, ME

An Honors Thesis

Presented to

The Faculty of The Department of Biology

Colby College

in partial fulfillment of the requirements for the

Degree of Bachelor of Arts with Honors

by

Julia Rogers

Waterville, ME

May 3, 2016

Advisor: Cathy D. Collins

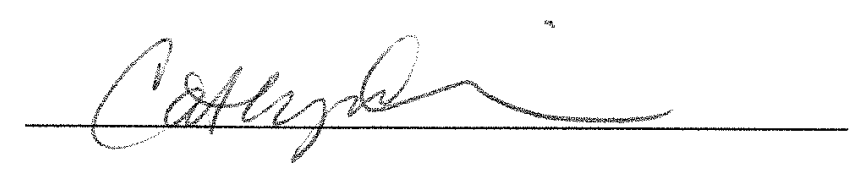

Reader: Judy Stone

Reader: Herb Wilson

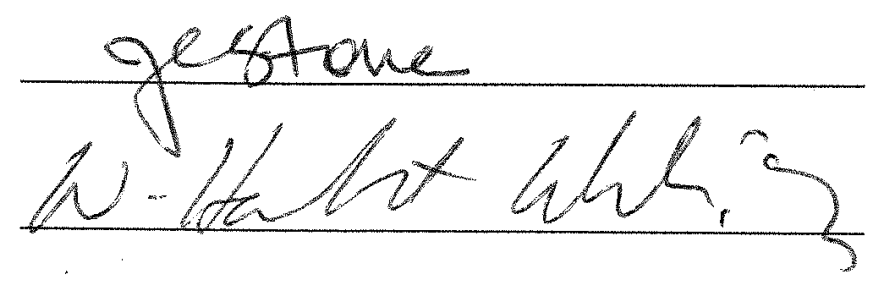




\section{Table of Contents}

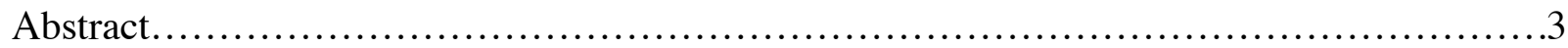

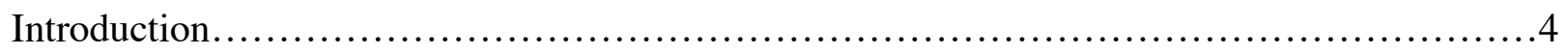

Methods...........................................................................

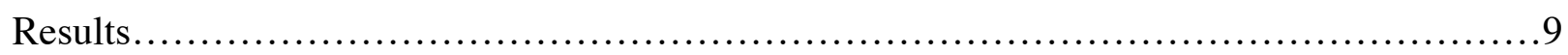

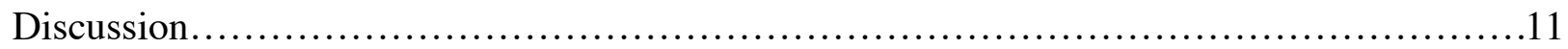

Conclusion................................................................... 14

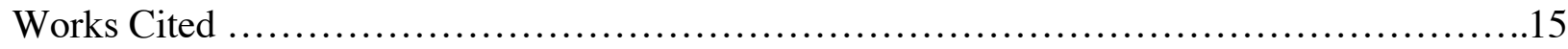

Acknowledgements..............................................................22

Tables.......................................................................23

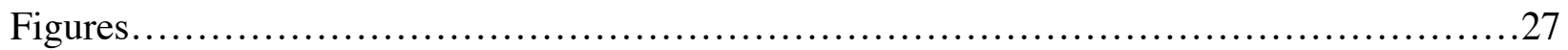

This paper has been formatted for submission to Northeastern Naturalist. 


\begin{abstract}
Non-native earthworms are found throughout much of the United States and southern Canada in areas that were glaciated during the most recent glaciation. These earthworms are changing nutrient cycling, modifying soil structure, and influencing diversity in forests throughout the Northern United States, and their invasion northward is facilitated by human activities. Although worms are present in compost piles and gardens of all Maine counties, there are no comprehensive studies of earthworms distributions in forested areas of Maine. I documented the presence and absence of earthworms in forested recreation areas in Kennebec County, Maine, and investigated ecological and landscape level variables that may predict their presence or absence. To examine whether the presence of worms may alter forests they have invaded, I also measured environmental variables known to be affected by worms in forests with and without worms. I found earthworms at 12 out of 23 sites, and the single significant factor for predicting earthworm presence was the distance to roads: sample sites near roads were more likely to have earthworms. I also found that locations with worms have less litter and more phosphorous in the soil. My study is the first study to explore the distribution of earthworms in Kennebec County and my findings provide evidence that roads facilitate earthworm invasion, and that there are measurable differences in the soils where earthworms are present.
\end{abstract}




\section{Introduction}

Earthworms introduced into previously glaciated regions of North America are considered invasive (Bohlen et al. 2004a). Their spread northward is facilitated by humans, through mechanisms such as roads, gardening, logging, and fishing (Bohlen et al. 2004a, Holdsworth et al. 2007, Kalisz and Dotson 1989, and others). Knowledge about the general spread, distribution, and effects of invasive earthworms is lacking throughout much of North America, particularly in Maine where few systematic earthworm surveys have been conducted. I surveyed sites in Kennebec County Maine to assess the distributional extent of earthworms and characterize the environmental factors associated with sites where they are present.

Earthworms have profound effects on the locations where they are found (Bohlen et al. 2004b, Davalos et al. 2013, Laossi et al. 2009), although the effects vary across ecosystems depending on forest composition, land use history, and soil type (Frelich et al. 2006). For instance earthworms alter carbon, phosphorous, and nitrogen levels through their consumption of organic matter, which in turn affects both above ground plant communities (Bohlen et al 2004b, Cassin and Kotanen 2016 Frelich et al 2006, Scheu and Parkinson 1994, Hale et al 2008) and below-ground microbial communities (Alban and Berry 1994, Bohlen et al 2004b). The magnitude of these effects depends on the earthworm species present and the ecosystem. In addition to affecting nutrients for both plants and micro-arthropods, earthworms that burrow deep into the soil, such as Lumbricus terrestris, bury seeds, decreasing seedling survival (Laossi et al. 2009). However, earthworms may also enhance seedling emergence by decreasing nutrient limitations to the seed (Milcu et al. 2006). A recent study shows that earthworms remove seeds from the soils potentially changing the composition of plant communities in forests (Cassin and Kotanen 2016). Due to the lack of consistency in overall earthworm effects on soils and plants, it 
is important to study earthworms in across a range of ecosystems to better understand their impacts.

Given the dramatic influence of worms on ecosystem properties, recent efforts have been made to identify environmental factors that predict earthworm presence or absence (Cameron et al. 2007, Costello et al. 2011, Gundale et al. 2005, Sackett et al. 2012, Suarez et al. 2006). For instance, forest type is the strongest predictor of earthworm presence in New York, where earthworms were more likely to be found in mixed hardwood forests than beech and hemlock forests (Suarez et al. 2006). Disturbance, too, plays a key role in predicting the locations of earthworms. Earthworms are more likely to be found near agricultural clearings (Suarez et al. 2006), close to fishing sites, and along roads experiencing regular vehicle traffic (Cameron et al. 2007, Sackett et al. 2012). Additionally, earthworms are associated with non-wilderness sites more than wilderness sites, a pattern likely explained by the presence of roads and logging (Gundale et al. 2005).

In Maine, little is known about the distribution of earthworms in natural landscapes. Reynolds (2008) recorded earthworms as present in each of Maine's counties; however his sampling effort was restricted to backyards, compost piles, and towns. Owen and Galbraith (1989) studied earthworms in relation to woodcock populations in six townships in central and eastern Maine. They found that areas that were farmed previously were the most likely to have earthworms regardless of other characteristics, and that worms were more abundant in moderately drained fine sandy loamy soils than in other soil types (Owen and Galbraith. 1989). The lack of formal study of earthworms in Maine coupled with the potential dramatic effects on forest ecosystems by invasive earthworms, highlights the need for further research in Maine - a state with about $90 \%$ forest cover, much of which is used for logging and recreation, and 
therefore vulnerable to human-mediated earthworm invasion. Moreover, many forests in Maine are younger forests, and earthworms better establish in younger forests than in old growth forests (Simmons et al. 2015).

I explored the distribution of earthworms and how ecological factors changed in areas with and without worms. My objectives were to (1) survey forests to record the extent of presences in Kennebec County, ME, (2) identify landscape and soil factors that predict earthworm presence, and (3) to investigate the effects of earthworms on the soils. Based on studies conducted in forests in other states, I expected that distance to roads and soil composition will be the most significant factor in predicting earthworm presence. Moreover, I expected to find that earthworms will reduce litter quantity, and alter the quantity of $\mathrm{N}$ and $\mathrm{P}$ in the soil.

\section{Methods}

\section{Study Locations}

I selected 23 study sites in Kennebec County, Maine. The average temperatures in Maine in January and June are $-2.4{ }^{\circ} \mathrm{C}$ and $23.2{ }^{\circ} \mathrm{C}$ respectively and the average precipitation is $991 \mathrm{~mm}$ (Weather Underground 2016). All sample sites were designated conservation and recreation areas and included forest at least one hectare in size. A total of 36 transects were established to sample for earthworms (Fig. 1). The number of transects per site was dictated by the number of soil types per conservation area. On each soil type, I haphazardly selected a location for one transect; all transects were within two miles of a paved road. There were ten different soil types (Table 1). I sampled all locations for earthworms between September 22, 2015 and November 3, 2015, as earthworms are known to be most active during the spring and fall months (Gates 1961). A subset of 21 transects were sampled a second time during the latter part of that period due to a marked increase in earthworm abundance following rain and cooler temperatures. 
Because I did not find worms in any places where I had recorded them absent before, resampling increased my confidence that the absence of worms from sites during the initial sampling was not caused by lower worm activity-levels. Not all sites were re-sampled due to freezing weather that decreased earthworm activity.

Transects were each 50 meters long and located at least five meters from human disturbance (e.g. trails). I sampled worms from five $25 \mathrm{~cm} \mathrm{x} 25 \mathrm{~cm}$ plots located at 10 meter intervals along the transect. I avoided placing plots within $1 \mathrm{~m}$ of any decomposing stump, branch, or tree, and at least one meter from any tree larger than 10 centimeters in diameter at breast height (dbh).

\section{Transect-level data}

For each transect, I recorded aspect and slope angle using a compass and a Nikon Forestry Pro Laser Rangefinder $@$ ․ To collect data on the forest composition, I established belt transects by expanding the 50 meter worm-sampling transect to include two meters on either side. Within the belt (200 $\mathrm{m}$ sq total), I measured and identified to species all trees larger than 10

centimeters in dbh. Basal area was calculated using the formula $B A_{\text {transect }}=\frac{\pi}{40000} * d b h^{2}$, where BA is basal area, and dbh represents diameter at breast height for each tree. I converted BA to basal area per hectare based on the formula, $B A_{\text {hectare }}=\sum B A_{\text {transect }} * 10000$, which summed the basal area for the transect and converted it to hectares.

To characterize soil attributes, I collected 6.2 cubic centimeters of soil from the top 10 $\mathrm{cm}$ of soil (after clearing litter) at each sub-plot and combined them into a single sample per transect. Soils were air-dried for two weeks prior to analysis. Soil moisture holding capacity was measured by taking the difference in mass of soils wetted to approximately field capacity, and soil mass after being oven dried at $105^{\circ} \mathrm{C}$ for 72 hours (Brudvig and Damschen 2011). Nutrient 
and texture analyses were conducted by Brookside Laboratories, Inc. (New Knoxville, OH) (www.blinc.com). I focused my analyses on percent silt, sand, and clay, $\mathrm{pH}$, nitrogen levels, organic matter, and phosphorus levels. These soil characteristics were chosen because other studies have shown that they affect earthworm presence (Table 2).

Earthworms were collected and counted at each of the five plots along the transects. I first cleared litter and hand-collected worms on the surface. To stimulate emergence of worms below ground, I poured a solution of 3.8 liters of water and $40 \mathrm{~g}$ of mustard seed powder on the area. I collected emerging worms for ten minutes per plot. Worms were brought back to the laboratory, measured, and then stored in $70 \%$ ethanol solution.

\section{Statistical Analysis}

All statistical analysis was conducted in R version 3.2.2 (R Core Team, 2015) and ArcGIS. ArcGIS was utilized to obtain forest size, Euclidean distance measurements for nearest roads and water, and soil types based on soil map data from the USGS Web Soil survey. Using current literature, I divided the soil variables into those influencing earthworm presence and those responding to earthworm presence (Table 2). I assessed the influence of landscape level variables (distance to roads, distance to water, and forest size), soil factors that were less likely to be changed by worms (soil texture, soil moisture, and $\mathrm{pH}$ ) and the ratio of coniferous to deciduous trees in the forest in a generalized linear model (GLM). With this modeling approach, we can specify a binomial error structure to accommodate binary (presence-absence) data. For model selection, I started with a full model including soil $\mathrm{pH}$, soil texture (as percent sand and percent silt), distance to roads, distance to water, and forest composition. I then removed each factor individually in order of least significance and tested for model significance to create the simplest model. I used Akaike information criteria (AIC) to select the best-fitting model. 
To determine the effect of earthworms on soil properties I first used nonmetric multidimensional scaling (NMDS) to visualize the data. I included percent soil organic matter, average litter depth $(\mathrm{cm})$, soil estimated nitrogen release (N/acre), and soil phosphorous levels $(\mathrm{mg} / \mathrm{kg})$, which have previously been shown to be affected by earthworms (Table 2$)$. The soil properties that we used in these tests were ones that had previously been shown to be affected by earthworms (Table 2). To ensure that factors left in the final model were not correlated, I ran linear regressions between forest composition and $\mathrm{pH}$, as well as forest size and distance to roads.

I then used a permutation multivariate analysis of variance (PERMANOVA) from the "vegan" package in R to test whether sites with worms versus those with worms differed with respect to the combined effect of these environmental factors. I also conducted t-tests to test the hypothesis that worm presence influenced individual soil properties.

\section{Results}

Earthworms were found at 12 out of 23 sites throughout Kennebec County (Fig. 2). Three sites included transects where worms were present and where worms were absent. In the 22 transects that were re-sampled, all presences and absences were confirmed.

The full model included variables most likely to affect the presence or absence of worms as reported in the literature (Table 2). Therefore, this model included $\mathrm{pH}$ of the soil, percent silt and percent sand, soil moisture holding capacity (SMHC), the ratio of coniferous to deciduous trees, distance to roads, distance to bodies of water, and forest size (Table 3).Following model selection, our final model included distance to roads, $\mathrm{pH}$, forest composition, and forest size

(Table 4). This model was significantly better than the full model (AIC final model =33.02, AIC 
full model=43.80). Distance to roads was the only statistically significant predictor for worm presence (Table 4, Fig. 3), although pH, forest composition, and forest size were marginally significant and retaining them improved model fit. Invasive earthworms were more likely to be found near roads, and the average distance to roads of sites with earthworms was 156.32 meters $( \pm 25.67 \mathrm{SE})$ and the mean distance was 372.99 meters $( \pm 61.87 \mathrm{SE}) \quad$ where they are absent. All distances ranged from 26.0 meters to 869.65 meters. The average $\mathrm{pH}$ increased under the presence of earthworms: the mean $\mathrm{pH}$ without earthworms was $4.92( \pm 0.05 \mathrm{SE})$, and the mean with earthworms was $5.08( \pm 0.06 \mathrm{SE})$, and the $\mathrm{pH}$ at all sites ranged from 4.6 to 5.5. Forests where earthworms were present were on average smaller with an average size of 145.18 hectares $( \pm 44.47 \mathrm{SE})$, and the average size of forests without earthworms was 412.65 hectares $( \pm 90.62$ SE). Lastly, the ratio of coniferous to deciduous trees was slightly smaller under the presence of earthworms a mean of $0.44( \pm 0.14 \mathrm{SE})$, and without earthworms the mean was $1.12( \pm 0.48 \mathrm{SE})$. Additionally, I found that there was no correlation between $\mathrm{pH}$ and the ratio of conifers and deciduous trees $\left(\mathrm{R}^{2}=0.05, \mathrm{p}=0.19\right)$. There is no correlation between forest size and distance to $\operatorname{road}\left(\mathrm{R}^{2}=0.02, \mathrm{p}=0.21\right)$.

Transects where worms are present differed with respect to soil attributes relative to transects where worms were present and transects where worms were absent $\left(\right.$ Fig $4, \mathrm{~F}_{35}=5.692$, $\mathrm{p}=0.002$, PERMANOVA). When soil attributes are analyzed separately, transects with earthworms have significantly higher levels of phosphorus and lower litter depths (Fig 5, Table 5). Levels of organic matter and nitrogen did not differ between sites with and without worms (Fig. 5, Table 5).

\section{Discussion}


My study illustrates that earthworms are found throughout Kennebec County, particularly near roads (regardless of soil type). Furthermore, soil characteristics differ between sites with and without earthworms, suggesting that the presence of earthworms may alter ecosystem properties of forests. To my knowledge, my study is the first to document the distribution of worms in Maine forests, particularly with respect to environmental variables.

As we predicted, earthworms were most-likely to be present near roads. These findings are congruent with other studies that suggest that earthworms are generally found closer to roads, especially older roads, along forest edges, near logging sites, or near other human disturbances (Beausejour et al. 2014, Bohlen et al. 2004a, Cameron and Bayne 2009, 2015, Gundale et al. 2005, Holdsworth et al. 2007, Randsom et al. 2015, Sackett 2012, Shartell et al. 2015). In Maine, I interpret the fact that distance to roads is the only significant predictor in our model as evidence that earthworms are spread via human travel as well as during road construction, possibly via substrate attached to the tires of vehicles (Marinissen and van den Bosch 1992). Moreover, this predicted mechanism for the spread of earthworms through Maine has interesting consequences due to the small population size in Maine and the distribution of towns. Earthworms may not have the vectors to get to certain locations throughout the state as most roads are found in the southern and eastern portions of the state. Additionally, roads in the rural parts of Maine may not have sufficient traffic to spread earthworms.

Forest size, forest composition, and $\mathrm{pH}$ were not statistically significant predictors for worm presence; however their inclusion in the best-fit model indicates that they are important factors in predicting the presence of earthworms at a site. Other studies also find that the forest composition and higher $\mathrm{pH}$ may be important indicators for the presence of earthworms (Frelich et al. 2006, Suarez et al. 2006), possibly due to inhospitable conditions found in forests 
dominated by conifers (Suarez et al. 2006). However, my data do not support this hypothesis as there is no correlation between $\mathrm{pH}$ and the ratio of conifers and deciduous trees, although $\mathrm{pH}$ is not the only reason conifer forests can be inhospitable. One reason I do not see a correlation here may be because most of the forests I studied were dominated by deciduous trees. Forest size indicates the influence of anthropogenic disturbance on the presence of earthworms. There is no correlation between forest size and distance to road, indicating that simply because there are smaller forests does not mean that the distance to road is the factor influencing this. However, smaller patches of forests have a greater edge to area ratio such that there is more edge in these patches. Gibson et al. (2013) found that for some groups of earthworms occurrence is higher on the edges of forests relative to the interior.

We detected no environmental predictors for the presence of earthworms, indicating that earthworms have the capacity to live in many different soil habitats, as long as they can get there. For example, worm presence did not appear to be linked to soil type, as I found earthworms in 7 out of the 10 soil types. Further, some of these soil types contained multiple transects, that differed with respect to presence of worms. Thus, access to soils - not texture or other attributes of soils-appears to dictate worm presence.

As I hypothesized, I found that soil phosphorous and litter depth were significantly different in areas where with worms than areas without worms. Specifically, lower litter depth and higher phosphorous characterized sites where earthworms were present. Low litter depths likely reflect the fact that earthworms consume litter; this, in turn changes the nutrient cycling and the plants that will thrive in those environments (Frelich et al. 2006, Gonzalez et al. 2003, Heneghan et al. 2007, Liu and Zou 2002). Many studies suggest that for the most part we expect to see a net loss of $\mathrm{P}$ with an increase in $\mathrm{P}$ leaching in the presence of earthworms (Frelich et al. 
2006, Resner et al. 2014). They also indicate that the effects on phosphorous levels in the soil depend upon the presence of certain species of earthworms and how long they have been present at that site (Frelich et al. 2006, Resner et al. 2014). For instance, the presence of $L$. terrestris, a species that burrows through from the litter deep into the soil may help explain my results. $L$. terrestris is thought to bring soils from deeper horizons to the surface, increasing the available phosphorous in the soil (Frelich et al 2006).

Unlike other studies (Alban and Berry 1994, Bohlen et al. 2004a, Burtelow et al. 2007, Groffman et al. 2015), I detected no difference in nitrogen and organic matter related to the presence or absence of worms. It is possible that I did not find a difference in nitrogen levels due to different characteristics of the sites. Some studies suggest that sites with historic earthworm activity demonstrate an increase in nitrogen levels (Haimi and Huhta 1990, Scheu 1987) while those with recent invasions show a decrease in nitrogen levels (Burtelow et al. 1998, Scheu and Parkinson et al. 1994). Therefore, the time since invasion could be an important factor in determining whether or not there is a change and the direction of the change in nitrogen levels in the soil. Perhaps in Maine there are many different invasion times based on when roads were constructed or when logging projects occurred. It is possible that this could be reflected in both the nitrogen levels and the organic matter.

The changes to the soil and litter layer by earthworms will likely influence plant communities present where earthworms have invaded - and some of these changes could yield economic impact as well. For instance, Lawrence et al. (2003) found that earthworms reduce the colonization and decrease presence of hyphae in mycorrhizal fungi associated with sugar maples negatively impacting the ability of maples to acquire adequate nutrients. Effects on soil fungi are widespread, leading to an observed shift from fungal-dominated soil to a bacterial system that is 
faster cycling (Bohlen et al. 2004b). Moreover, studies suggest that earthworms create conditions conducive for invasive plant species, including buckthorn, garlic mustard, and multiflora rose mainly due to the disturbance (Clause et al. 2014, Hopfensperger and Hamilton 2015, Nuzzo et al. 2015, Roth et al. 2014, Whitfeld et al. 2014,). Other studies suggest that most native plant species do not benefit from earthworm presence, and that rare species are negatively affected resulting in changes to the forest composition. Recently, studies suggest that earthworms may be decreasing seeds in the soil, both native and invasive, but that in the forests these effects are masked by rodent seed predation (Cassin and Kotenen 2016).

Other factors that may relate to earthworm distribution include land-use history, proximity to wetlands, proximity to agricultural fields, or proximity to logging operations (Cameron et al. 2007, Costello et al. 2010, Gundale et al. 2005, Suarez et al. 2006, Sackett et al. 2012). In Kennebec County, the majority of forests have been logged since the 1800 s, as was most of the state of Maine (Moore and Whitham 1996). Most land was then used as farm-land, and later abandoned and allowed to return to forests (Moore and Whitham 1996). Based on other studies in the region, studying worm distribution in relation to proximity to agriculture and landuse history (especially in relation to areas that were previously farmed) will help us better interpret current patterns, as well as predict the location of future invasion (Owen and Galbraith 1989, Suarez et al. 2006).

\section{Conclusion}

My study suggests that earthworms could be found throughout much of the state of Maine especially where there are disturbances to the forests, such as near roads. Additionally, earthworms have the potential to change the forests where they are found. Since much of Maine's forests experience disturbances and are found near roads, whether they are paved or are 
logging roads, they have strong potential for earthworm invasion. Further study throughout the state of Maine to investigate where earthworms are found throughout forests throughout the state will be necessary to understand their impact throughout the state. Considering earthworms may have significant impact on economically valuable trees, further investigation is necessary.

\section{Literature Cited}

Alban, D.H., and E.C. Berry. 1994. Effects of earthworm invasion on morphology, carbon, and nitrogen of a forest soil. Applied Soil Ecology 1:243:249.

Beauséjour, R., I.T., Handa, M.J. Lechowicz, B. Gilbert, and M. Vellend. 2015. Historical anthropogenic disturbances influence patterns of non-native earthworm and plant invasions in a temperate primary forest. Biological Invasions 17:1267-1281.

Bohlen, P.J., S. Scheu, C.M. Hale, M.A. McLean, S. Migge, P.M. Groffman, and D. Parkinson. 2004a. Non-native invasive earthworms as agents of change in northern temperate forests. Frontiers in Ecology Environments 2:427-435.

Bohlen, P. J., D.M. Pelletier, P.M. Groffman, T.J. Fahey, and M.C. Fisk. 2004b. Influence of earthworm invasion on redistribution and retention of soil carbon and nitrogen in northern temperate forests. Ecosystems 7:13-27.

Brudvig, L. A., and E.I. Damschen. 2011. Land-use history, historical connectivity, and land management interact to determine longleaf pine woodland understory richness and 
composition. Ecography, 34:257-266.

Burtelow, A. E., P.J. Bohlen, and P.M. Groffman. 1998. Influence of exotic earthworm invasion on soil organic matter, microbial biomass and denitrification potential in forest soils of the northeastern United States. Applied Soil Ecology 9:197-202.

Cameron, E. K., and E.M. Bayne. 2009. Road age and its importance in earthworm invasion of northern boreal forests. Journal of Applied Ecology 46:28-36.

Cameron, E. K., and E.M. Bayne. 2015. Spatial patterns and spread of exotic earthworms at local scales. Canadian Journal of Zoology 93:721-726.

Cameron, E. K., E.M. Bayne, and M.J. Clapperton. 2007. Human-facilitated invasion of exotic earthworms into northern boreal forests. Ecoscience 14: 482-490.

Cassin, C.M., and P.M. Kotanen. 2016. Invasive earthworms as seed predators of temperate forest plants. Biological Invasions: 1-14.

Clause, J., E. Forey, C.J. Lortie, A.M. Lambert, and S. Barot. 2015. Non-native earthworms promote plant invasion by ingesting seeds and modifying soil properties. Acta Oecologica, 64:10-20.

Costello, D. M., S.D. Tiegs, and G.A. Lamberti. 2011. Do non-native earthworms in Southeast 
Alaska use streams as invasional corridors in watersheds harvested for timber? Biological Invasions 13:177-187.

Dávalos, A., V. Nuzzo, J. Stark, and B. Blossey. 2013. Unexpected earthworm effects on forest understory plants. BMC Ecology 13.

Dobson, A., and B. Blossey. 2015. Earthworm invasion, white-tailed deer and seedling establishment in deciduous forests of north-eastern North America. Journal of Ecology 103:153-164.

Frelich, L. E., C.M. Hale, S. Scheu, A.R. Holdsworth, L. Heneghan, P.J. Bohlen, and P.B. Reich. 2006. Earthworm invasion into previously earthworm-free temperate and boreal forests. Biological Invasions 8:1235-1245.

Gates, G. E. 1961. Ecology of some earthworms with special reference to seasonal activity. The American Midland Naturalist, 66:61-86.

Gibson, K.D., P.M. Quackenbush, N.C. Emery, M.A. Jenkins, and E.J. Kladivko. 2013. Invasive earthworms and plants in Indiana old- and second-growth forests. Invasive Plant Science and Management 6:161-174.

González, G., E. García, V. Cruz, S. Borges, M. Zalamea, and M.M. Rivera. 2007. Earthworm communities along an elevation gradient in Northeastern Puerto Rico. European Journal 
of Soil Biology 43:24-32.

Gonzalezir‘V, G., T.R. Seastedt, and Z. Donate. 2003. Earthworms, arthropods and plant litter decomposition in aspen (Populus tremuloides) and lodgepole pine. Pedobiologia 47:863869.

Groffman, P. M., P.J. Bohlen, M.C. Fisk, and T.J. Fahey. 2004. Exotic earthworm invasion and microbial biomass in temperate forest soils. Ecosystems 7:45-54.

Groffman, P. M., T.J. Fahey, M.C. Fisk, J.B. Yavitt, R.E. Sherman, P.J. Bohlen, and J.C. Maerz. 2015. Earthworms increase soil microbial biomass carrying capacity and nitrogen retention in northern hardwood forests. Soil Biology and Biochemistry 87:51-58.

Gundale, M.J. 2002. Influence of exotic earthworms on the soil organic horizon and the rare fern Botrychium mormo. Conservation Biology 16:1555-1561.

Gundale, M. J., W.M. Jolly, and T.H. Deluca. 2005. Susceptibility of a northern hardwood Forest to exotic earthworm invasion: earthworm invasion susceptibility. Conservation Biology 19:1075-1083.

Hale, C. M. L.E. Frelich, and P.B. Reich. 2006. Changes in hardwood forest understory plant communities in response to European earthworm invasions. Ecology 87:1637-1649. 
Hale, C. M., L.E. Frelich, P.B. Reich, and J. Pastor. 2008. Exotic earthworm effects on hardwood forest floor, nutrient availability and native plants: a mesocosm study. Oecologia 155:509-518.

Hale, C. M., P.B. Reich, and L.E. Frelich. 2004. Allometric equations for estimation of ash-free dry mass from length measurements for selected European earthworm species (Lumbricidae) in the Western Great Lakes Region. The American Midland Naturalist 151:179-185.

Haimi, J., and V. Huhta. 1990. Effect of earthworms on decomposition processes in raw humus forest soil: a microcosm study. Biology and Fertility of Soils 19: 178-183.

Heneghan, L., J. Steffen, and K. Fagen. 2007. Interactions of an introduced shrub and introduced earthworms in an Illinois urban woodland: Impact on leaf litter decomposition. Pedobiologia 50: 543-551.

Holdsworth, A. R., L.E. Frelich, and P.B. Reich. 2007. Effects of earthworm invasion on plant species richness in northern hardwood forests. Conservation Biology, 21:997-1008.

Hopfensperger, K. N., \& S. Hamilton. 2015. Earthworm communities in previously glaciated and unglaciated eastern deciduous forests. Southeastern Naturalist, 14:66-84.

Kalisz, P. J., and D.B. Dotson. 1989. Land-use history and the occurrence of exotic earthworms 
in the mountains of Eastern Kentucky. American Midland Naturalist, 122.

Kaushal, B. R., B. Kandpal, S.P. Bisht, S. Bora, and R. Dhapola. 1999. Abundance and seasonal activity of earthworms in croplands of Kumaon Himalayas. European Journal of Soil Biology 35:171-176.

Lawrence, B., M.C. Fisk, T.J. Fahey, and E.R. Suarez. 2003. Influence of nonative earthworms on mycorrhizal colonization of sugar maple (Acer saccharum). New Phytologist 157:145153.

Laossi, K.R., D.C. Noguera, A. Bartolomé-Lasa, J. Mathieu, M. Blouin, and S. Barot. 2009. Effects of an endogeic and an anecic earthworm on the competition between four annual plants and their relative fecundity. Soil Biology and Biochemistry 4:1668-1673

Liu, Z. G., and X.M. Zou. 2002. Exotic earthworms accelerate plant litter decomposition in a Puerto Rican pasture and a wet forest. Ecological Applications 12.

McLean, M.A., and D. Parkinson. 2000. Field evidence of the effects of the epigeic earthworm Dendrobaena octaedra on the microfungal community in pine forest floor. Soil Biology and Biochemistry 32:351-360.

McLean M.A., and D. Parkinson. 1998. Impacts of the epigeic earthworm Dendrobaena octaedra on orbatid mite community diversity and microarthropod abundances in pine 
forest floor: a mesocosm study. Applied Soil Ecology 7:125-136.

Mclean M.A., and D. Parkinson. 2000. Field evidence of the effects of the epigeic earthworm Dendrobaena octaedra on the microfungal community in pine forest floor. Soil Biology and Biochemistry 32:351-360.

Milcu, A., J. Schumacher, and S. Scheu. 2006. Earthworms (Lumbricus terrestris) affect plant seedling recruitment and microhabitat heterogeneity. Functional Ecology, 20:261-268.

Moore, E. H., and J.W. Witham. 1996. From forest to farm and back again: land use history as a dimension of ecological research in coastal Maine. Forest History 1:50-69

Nuzzo, V., A. Dávalos, and B. Blossey. 2015. Invasive earthworms shape forest seed bank composition. Diversity and Distributions 21:560-570.

Owen R.B. Jr, and W.J. Galbraith. 1989. Earthworm biomass in relation to forest types, soil, and land use: implications for woodcock management. Wildlife Society Bulletin 17:130-136.

Palm, J., N.L.M.B. van Schaik, and B. Schröder. 2013. Modeling distribution patterns of anecic, epigeic and endogeic earthworms at catchment-scale in agro-ecosystems. Pedobiologia $56: 23-31$

Ransom, T. S., and B.J. Billak. 2015. Differences in soil characteristics between field and forest 
may influence the distribution of an invasive earthworm. Invertebrate Biology 134:7887.

Resner, K., K. Yoo, S.D. Sebestyen, A. Aufdenkampe, C. Hale, A. Lyttle, and A. Blum. 2015. Invasive earthworms deplete key soil inorganic nutrients $(\mathrm{Ca}, \mathrm{Mg}, \mathrm{K}$, and $\mathrm{P})$ in a northern hardwood forest. Ecosystems 18:89-102.

Reynolds, J. W. 2008. The earthworms (Oligochaeta: Acanthodrilidae, Lumbricidae and Megascolecidae) of Maine, USA. Megadrilogica 12:61-72.

Roth, A. M., T.J.S. Whitfeld, A.G. Lodge, N. Eisenhauer, L.E. Frelich, and P.B. Reich. 2015. Invasive earthworms interact with abiotic conditions to influence the invasion of common buckthorn (Rhamnus cathartica). Oecologia 178:219-230.

Sackett, T. E., S.M. Smith, and N. Basiliko. 2012. Exotic earthworm distribution in a mixed-use northern temperate forest region: influence of disturbance type, development age, and soils. Canadian Journal of Forest Research 42:375-381.

Scheu, S. 1987. The influence of earthworms (Lumbricidae) on the nitrogen dynmaics in the soil litter system of a deciduous forest. Oecologia 72:197-201.

Scheu, S., and D. Parkinson. 1994. Effects of earthworms on nutrient dynamics, carbon turnover and microorganisms in soils from cool temperate forests of the Canadian Rocky 
Mountains - laboratory studies. Applied Soil Ecology 1:113-125.

Shartell, L. M., R.G. Corace, A.J. Storer, and D.M. Kashian. 2015. Broad and local-scale patterns of exotic earthworm functional groups in forests of National Wildlife Refuges of the Upper Midwest, USA. Biological Invasions 17:3591-3607.

Simmons, W., A. Dávalos, and B. Blossey. 2015. Forest successional history and earthworm legacy affect earthworm survival and performance. Pedobiologia 58:153-164.

Suárez, E. R., G.L. Tierney, T.J. Fahey, and R. Fahey. 2006. Exploring patterns of exotic earthworm distribution in a temperate hardwood forest in South-Central New York, USA. Landscape Ecology 21:297-306.

Whitfeld, T. J. S., A.M. Roth, A.G. Lodge, N. Eisenhauer, L.E. Frelich, and P.B. Reich. 2014. Resident plant diversity and introduced earthworms have contrasting effects on the success of invasive plants. Biological Invasions 16:2181-2193.

\section{Acknowledgements}

I would like to first and foremost thank my advisor, Cathy Collins for all of her assistance on this project. Without her help, this project would not have been possible. I would also like to thank my thesis committee, Judy Stone and Herb Wilson for their input and edits on my project. This project was supported by funds from the Colby Biology Department and the Dean of 
Students Special Funds. Moreover, I would like to thank the land owners and conservation organizations that allowed me to use their property for research.

\section{Tables}

Table 1. Location, soil type, and forest size of all transects.

\begin{tabular}{|c|c|c|c|}
\hline Transect & Location & Soil Type & $\begin{array}{l}\text { Forest Size(ha) } \\
\end{array}$ \\
\hline$\overline{\mathbf{A}}$ & Runnals Hill, Colby College & $\begin{array}{l}\text { Paxton Charlton very stony } \\
\text { fine sandy loam }\end{array}$ & 115 \\
\hline B & Runnals Hill, Colby College & Hollis fine sandy loam & 115 \\
\hline C & Perkins Arboretum, Colby College & Buxton silt loam & 76 \\
\hline D & Perkins Arboretum, Colby College & Buxton silt loam & 76 \\
\hline $\mathbf{E}$ & Quarry Road Ski Area, Waterville & Scantic silt loam & 81 \\
\hline $\mathbf{F}$ & Quarry Road Ski Area, Waterville & Hollis fine sandy loam & 81 \\
\hline $\mathbf{G}$ & Quarry Road Ski Area, Waterville & Buxton silt loam & 81 \\
\hline H & Mount Phillip, Rome & Lyman loam & 275 \\
\hline I & Mount Phillip, Rome & $\begin{array}{l}\text { Berkshire very stony fine } \\
\text { sandy loam }\end{array}$ & 275 \\
\hline $\mathbf{J}$ & Round Top, Rome & Lyman loam & 1019 \\
\hline $\mathbf{K}$ & Round Top, Rome & $\begin{array}{l}\text { Berkshire very stony fine } \\
\text { sandy loam }\end{array}$ & 1019 \\
\hline $\mathbf{L}$ & Round Top, Rome & Peru fine sandy loam & 1019 \\
\hline $\mathbf{M}$ & Sanders Hill, Rome & Lyman loam & 294 \\
\hline $\mathbf{N}$ & Sanders Hill, Rome & $\begin{array}{l}\text { Berkshire very stony fine } \\
\text { sandy loam }\end{array}$ & 294 \\
\hline $\mathbf{O}$ & French Mountain, Rome & Lyman loam & 205 \\
\hline $\mathbf{P}$ & Seaward Mills Vassalboro & Buxton silt loam & 43 \\
\hline $\mathbf{Q}$ & $\begin{array}{l}\text { Davidson Nature Preserve, } \\
\text { Vassalboro }\end{array}$ & Hollis fine sandy loam & 397 \\
\hline $\mathbf{R}$ & Vassalboro Wildlife Habitat & Scantic silt loam & 15 \\
\hline $\mathbf{S}$ & Vassalboro Wildlife Habitat & Buxton silt loam & 15 \\
\hline $\mathbf{T}$ & Woodsmen Field, Colby College & $\begin{array}{l}\text { Woodbridge very stony fine } \\
\text { sandy loam }\end{array}$ & 11 \\
\hline AA & Jamie's Pond WMA, Hallowell & $\begin{array}{l}\text { Paxton Charlton very stony } \\
\text { fine sandy loam }\end{array}$ & 290 \\
\hline $\mathbf{A B}$ & Reynolds Forest, Sidney & Suffield silt loam & 223 \\
\hline $\mathrm{AC}$ & Oxbow, Waterville & Scantic silt loam & 9 \\
\hline AD & Vaughan Woods, Hallowell & Suffield silt loam & 98 \\
\hline $\mathbf{A E}$ & $\begin{array}{l}\text { Woodbury Pond State Park, } \\
\text { Litchfield }\end{array}$ & $\begin{array}{l}\text { Paxton Charlton very stony } \\
\text { fine sandy loam }\end{array}$ & 38 \\
\hline $\mathbf{A F}$ & $\begin{array}{l}\text { Mt. Pisgah Conservation Area, } \\
\text { Winthrop }\end{array}$ & $\begin{array}{l}\text { Paxton Charlton very stony } \\
\text { fine sandy loam }\end{array}$ & 1144 \\
\hline
\end{tabular}




\begin{tabular}{|c|c|c|c|}
\hline $\mathbf{A G}$ & $\begin{array}{l}\text { Small-Burnham Conservation Area, } \\
\text { Litchfield }\end{array}$ & $\begin{array}{l}\text { Woodbridge very stony fine } \\
\text { sandy loam }\end{array}$ & 706 \\
\hline AH & $\begin{array}{l}\text { Small-Burnham Conservation Area, } \\
\text { Litchfield }\end{array}$ & $\begin{array}{l}\text { Hinckley gravelly sandy } \\
\text { loam }\end{array}$ & 706 \\
\hline AI & Parker Pond Headlands, Fayette & $\begin{array}{l}\text { Paxton very stony fine } \\
\text { sandy loam }\end{array}$ & 136 \\
\hline AJ & Torsey Pond, Mt. Vernon & $\begin{array}{l}\text { Woodbridge very stony fine } \\
\text { sandy loam }\end{array}$ & 92 \\
\hline $\mathbf{A K}$ & $\begin{array}{l}\text { MacDonald Conservation Area, } \\
\text { Readfield }\end{array}$ & $\begin{array}{l}\text { Woodbridge very stony fine } \\
\text { sandy loam }\end{array}$ & 424 \\
\hline $\mathbf{A L}$ & Hutchinson Pond, Manchester & $\begin{array}{l}\text { Woodbridge very stony fine } \\
\text { sandy loam }\end{array}$ & 166 \\
\hline $\mathbf{A M}$ & Wyman Memorial Forest, Readfield & Hollis fine sandy loam & 418 \\
\hline AN & Augusta Arboretum & Hollis fine sandy loam & 39 \\
\hline AO & Augusta Nature Center & Suffield silt loam & 24 \\
\hline $\mathbf{A P}$ & Augusta Nature Center & Hollis fine sandy loam & 24 \\
\hline
\end{tabular}

Table 2. A list of variables and observations in the literature. Those listed as predictor may affect the presence/absence of earthworms, and those listed as response, are those effected by earthworms

\begin{tabular}{|c|c|c|c|c|}
\hline Variable & Earthworm & Location & System & Study \\
\hline \multirow[t]{2}{*}{ Soil pH } & Predictor & Puerto Rico & Forest & Gonzalez et al 2007 \\
\hline & & Maine, USA & Forest & Owen and Gailbraith 1989 \\
\hline \multirow[t]{3}{*}{ Soil Texture } & Predictor & Germany & Agriculture areas & Palm et al 2013 \\
\hline & & Ontario, Canada & Forests & Sackett et al 2012 \\
\hline & & Maine, USA & Forests & Owen and Galbraith 1989 \\
\hline Soil Moisture & Predictor & Himalayas & Agricultural field & Kaushal et al 1999 \\
\hline \multirow[t]{3}{*}{ Distance to Roads } & Predictor & Alberta, Canada & Forests & Cameron et al 2007 \\
\hline & & MN and WI, USA & Forests & Holdsworth et al 2007 \\
\hline & & Ontario, Canada & Forests & Sackett et al 2012 \\
\hline \multirow[t]{2}{*}{ Distance to Water } & Predictor & New York, USA & Forests & Suarez et al 2006 \\
\hline & & MN and WI, USA & Forests & Holdsworth et al 2007 \\
\hline \multirow[t]{2}{*}{ Forest Composition } & Predictor & New York, USA & Forests & Suarez et al 2006 \\
\hline & & Maine, USA & Forests & Owen and Galbraith 1989 \\
\hline Soil N & Response & Minnesota, USA & Forests & Alban and Berry 1994 \\
\hline
\end{tabular}




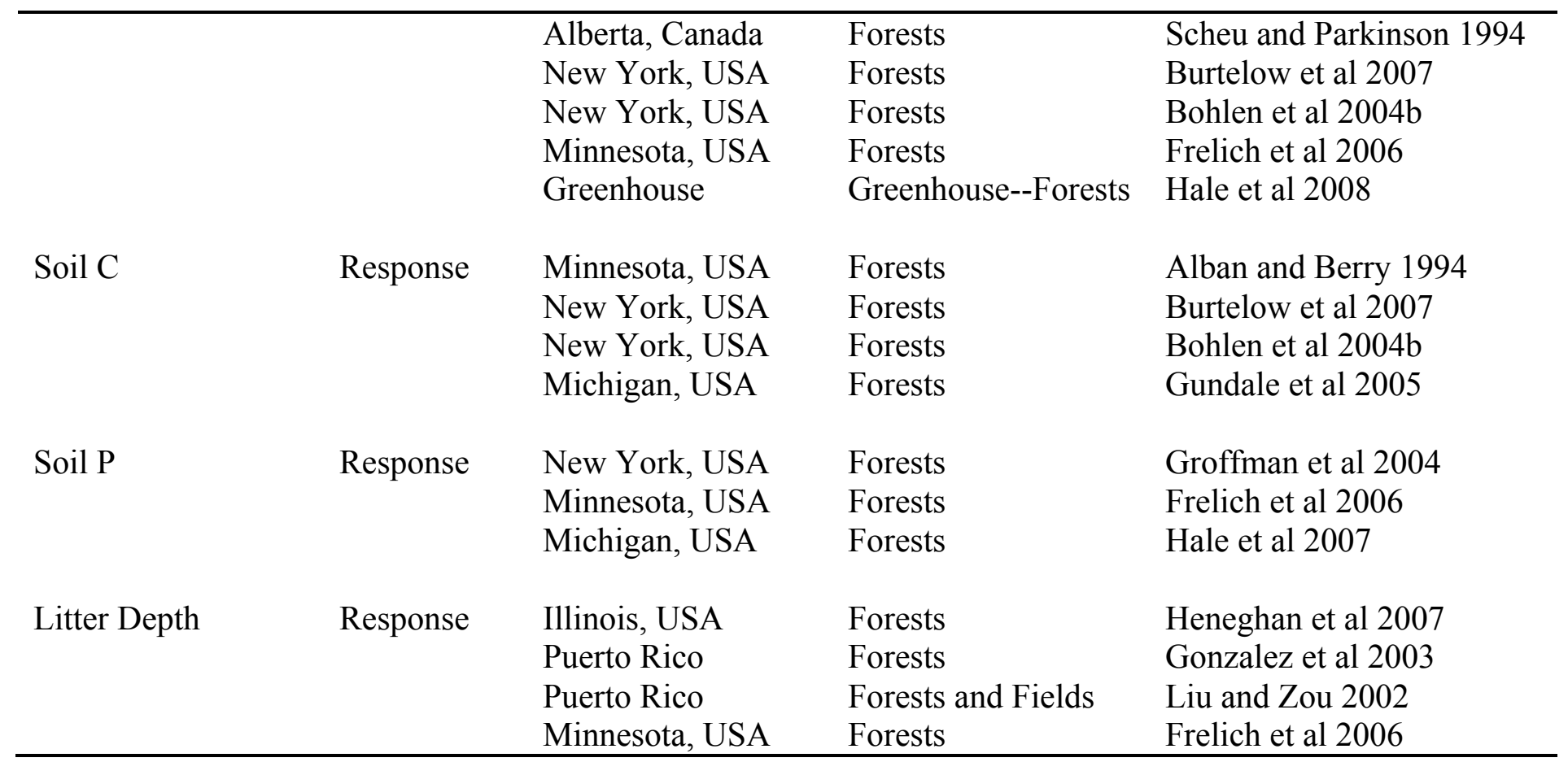

Table 3. All ecological and landscape level factors that may influence the presence of earthworms. SM is soil moisture, DisRoad is the distance to roads, SA.per is the percent sand, CD.ratio is the coniferous/deciduous ratio. The last four rows show the interaction between distance to roads and the variables.

\begin{tabular}{lllll} 
& Estimate & Std. Error & z value & p \\
\hline \hline Intercept & -81420 & 63030 & -1.292 & 0.196 \\
pH & 15090 & 11960 & 1.262 & 0.207 \\
DisRoad & 0.1639 & 0.1903 & 0.861 & 0.389 \\
SA.per & 0.003985 & 0.2064 & 0.019 & 0.985 \\
SM & 0.2593 & 0.221 & 1.173 & 0.241 \\
CD.ratio & $-1.01 \mathrm{E}+00$ & $2.21 \mathrm{E}+00$ & -0.46 & 0.646 \\
Distance to Water & 0.0006517 & 0.005352 & 0.122 & 0.903 \\
Forest Size & -0.006145 & 0.004769 & -1.288 & 0.198 \\
pHxDisRoad & -0.02497 & 0.03398 & -0.735 & 0.462 \\
DisRoadxSA.per & -0.00008652 & 0.0008137 & -0.106 & 0.915 \\
DisRoadxSM & -0.001035 & 0.0008714 & -1.188 & 0.235 \\
DisRoadxCD.ratio & -0.003068 & 0.01149 & -0.267 & 0.789 \\
\hline
\end{tabular}

Table 4. Results from final model with soil $\mathrm{pH}$, distance to roads, coniferous to deciduous ratio, and forest size. 


\begin{tabular}{lcccc}
\hline & Estimate & Std. Error & z value & $\mathbf{p}$ \\
\hline \hline Intercept & -22.499555 & 12.957401 & -1.736 & 0.0825 \\
pH & 5.572796 & 2.844974 & 1.959 & 0.0501 \\
DisRoad & -0.011505 & 0.005243 & -2.194 & $\mathbf{0 . 0 2 8 2}$ \\
CD.ratio & -1.804216 & 0.990264 & -1.822 & 0.0685 \\
Forest & -0.004295 & 0.002192 & -1.959 & 0.0501 \\
\hline
\end{tabular}

Table 5. Results from two sample t-tests for soil factors including nitrogen, phosphorus, litter depth, and percent organic matter.

\begin{tabular}{llll}
\hline Test & $\mathbf{t}$ & df & p-value \\
\hline N Presence & 1.2787 & 34 & 0.2097 \\
P Presence & -2.2482 & 33.788 & $\mathbf{0 . 0 3 1 2}$ \\
LD Presence & 4.9615 & 20.591 & $<0.001$ \\
OM Presence & 1.5666 & 32.318 & 0.1269 \\
\hline
\end{tabular}




\section{Figures}

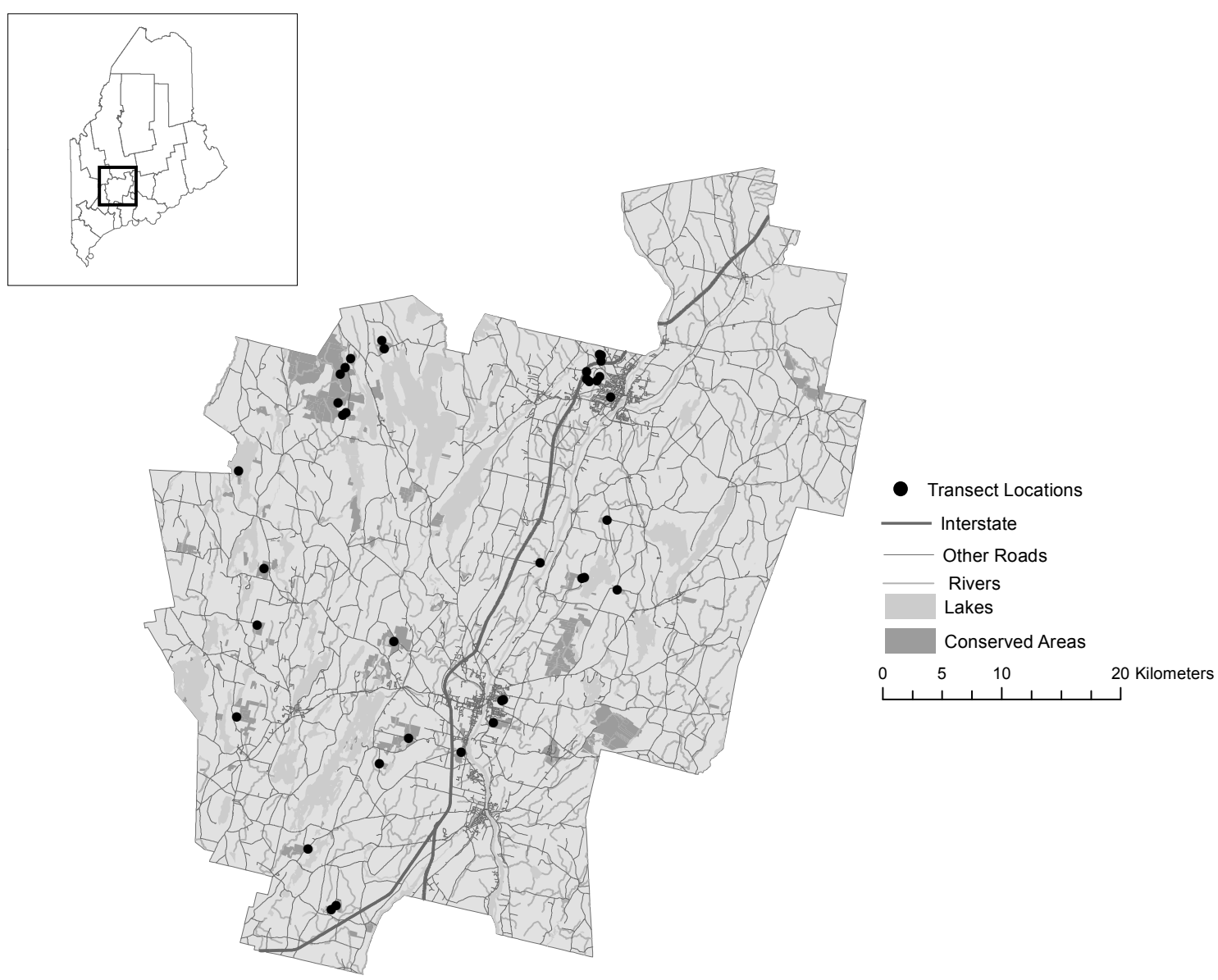

Figure 1. A map illustrating the locations of transects throughout Kennebec County, ME. 

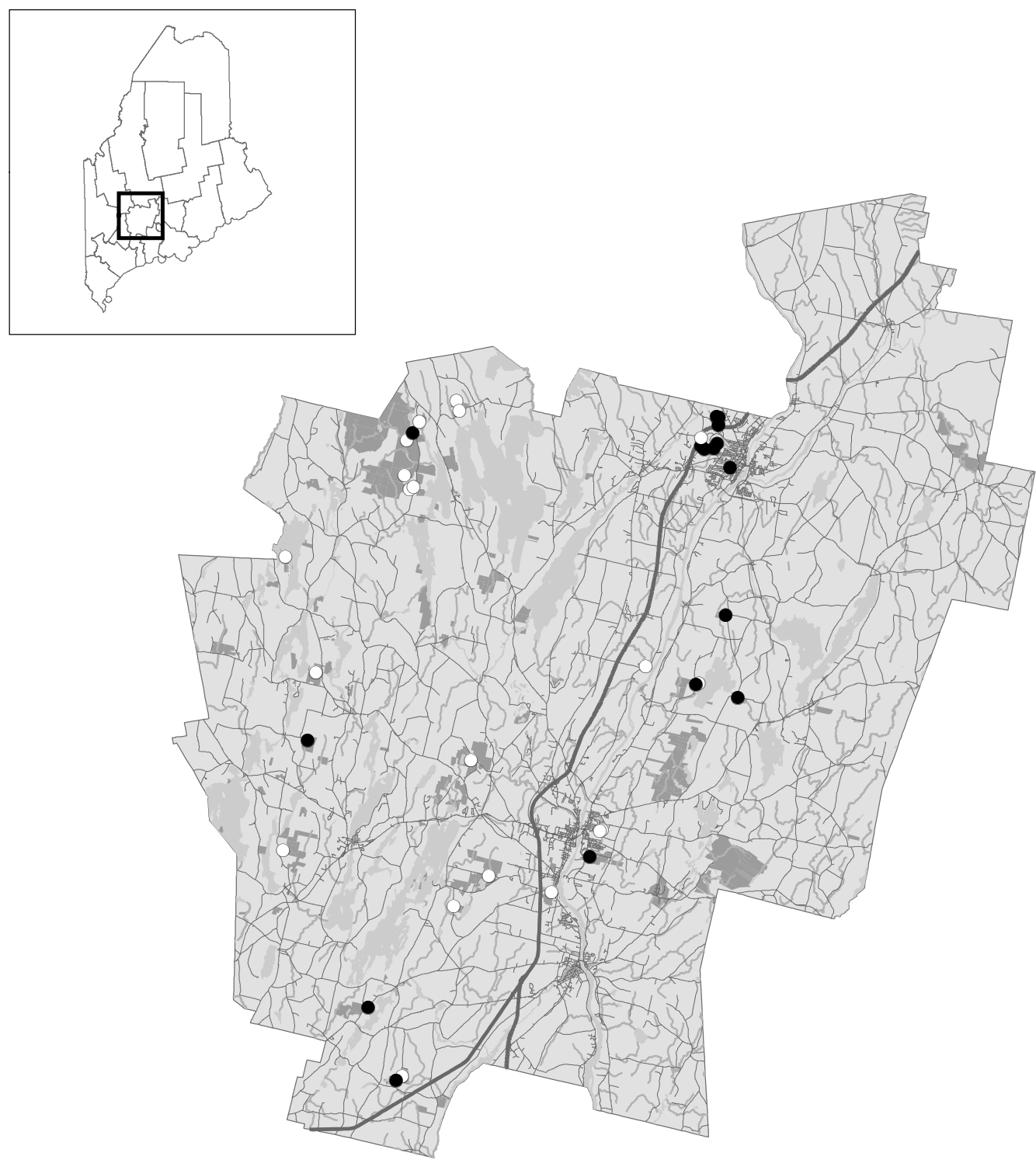

- Transects where worms are absent

- Transects where worms are present Interstate

Other Roads

Rivers

Lakes

Conserved Areas

$\begin{array}{llll}0 & 5 & 10 & 20 \text { Kilometers }\end{array}$

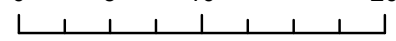

Figure 2. A map of Kennebec County showing transects where worms are presents and transects where worms are absent. 


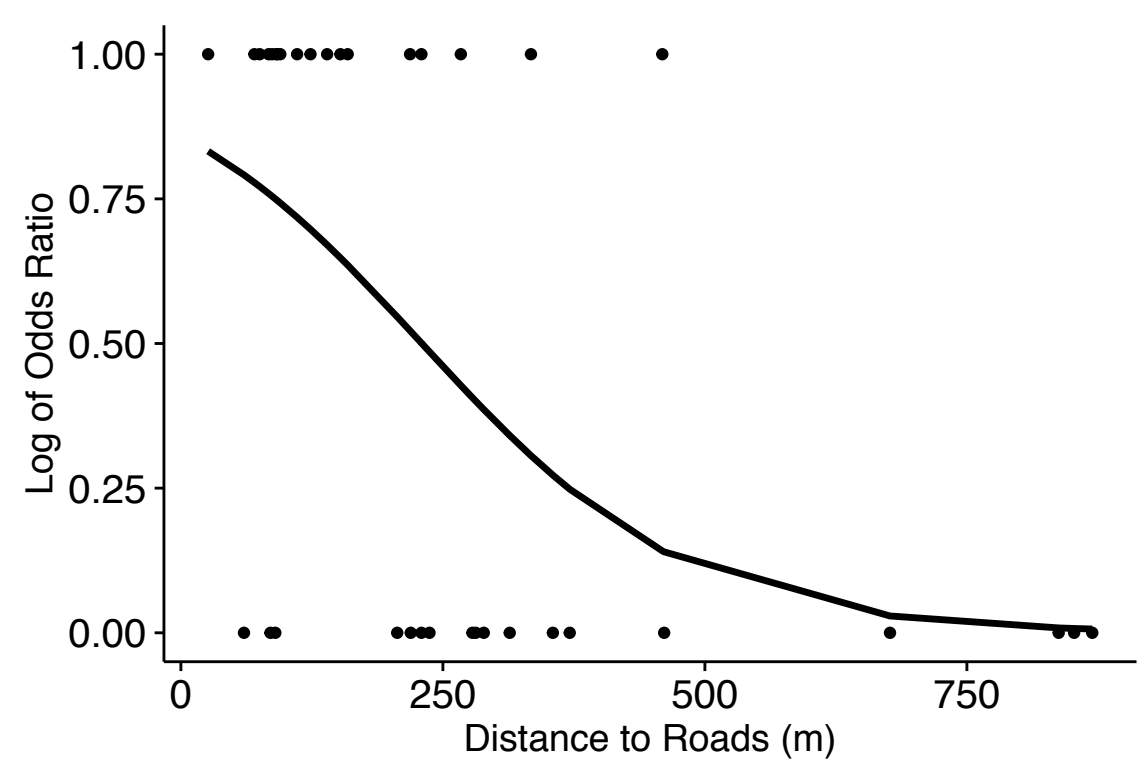

Figure 3. Results from linear model of distance to roads and the linear log probability of encountering worms

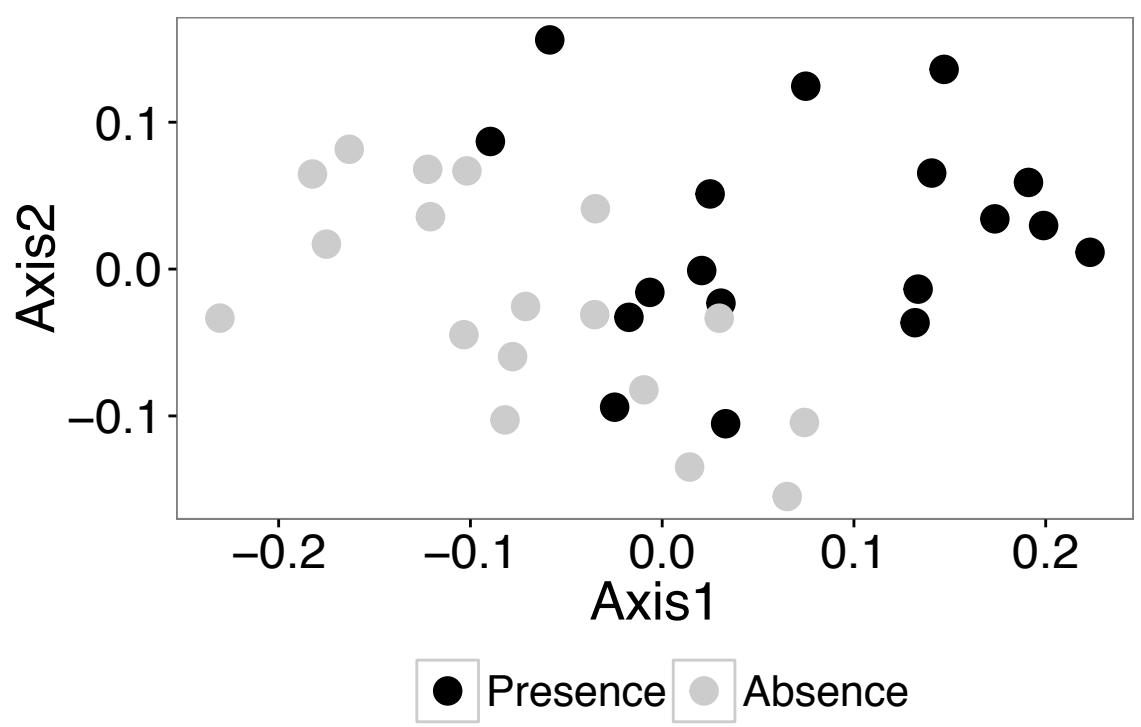

Figure 4. NMDS of soil variables estimated nitrogen release, soil phosphorous, litter depth, and percent organic matter. 

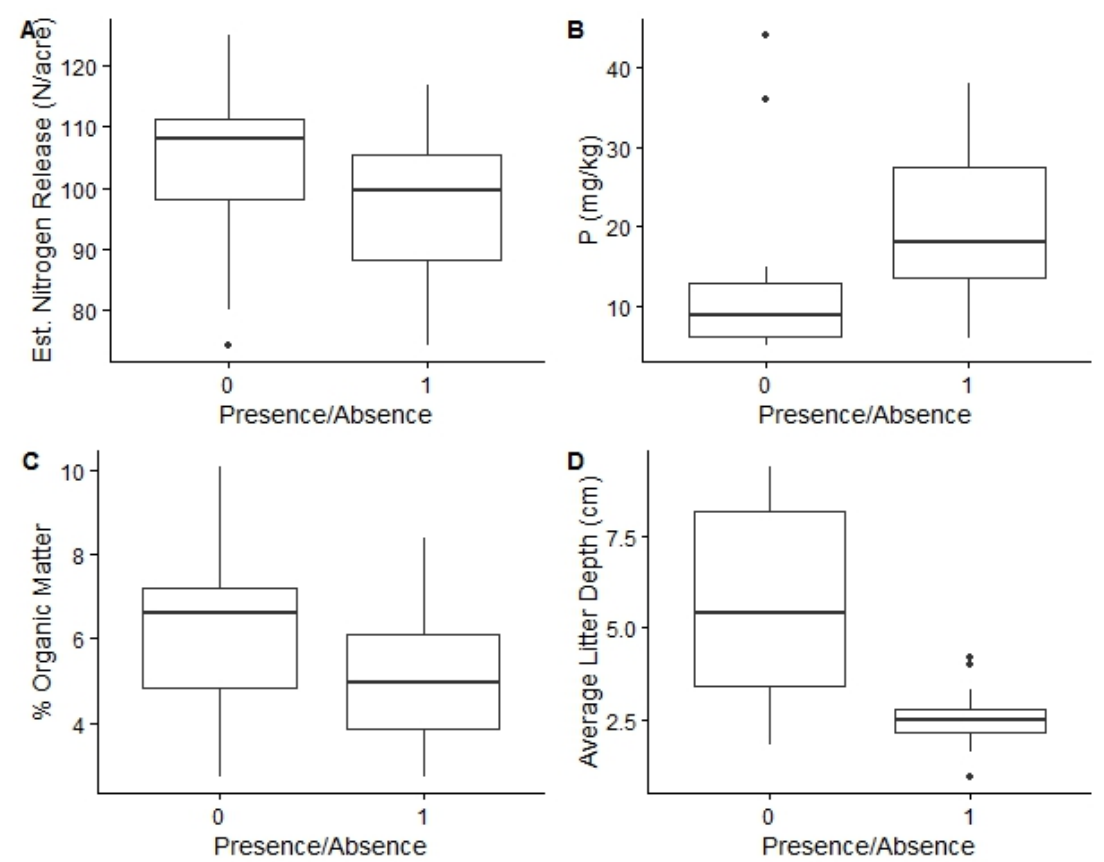

Figure 5. Boxplots of soil factors that may be affected by earthworms. 